\title{
Mapping the social space of transnational migrants on the basis of their (supra)national belongings: The case of French citizens in Berlin. ${ }^{1}$
}

\section{Cédric Duchêne-Lacroix ${ }^{2}$ and Angeliki Koukoutsaki-Monnier ${ }^{3}$}

\begin{abstract}
In traditional migration theory, social self-identification is usually linked with the process and quality of integration and with the nationality of the countries of 'origin' and of residence. But in the context of a supranational integrated area like the European Union, the self-identification of European people living (also) abroad in another European country can be more complicated. What sorts of identity combinations do they produce in this situation? Could we interpret their choice in the light of their social, economic, cultural capitals and (multi)local integration? Based on an empirical analysis of French citizens in Berlin this article confirms that identity self-combining - not just the identity elements - and the position of the ego in the social space are linked. The meaning of the same identity category depends on respondent's profiles.
\end{abstract}

Keywords: National Identity, European identity, transnational migration, expatriates, social space, habitus

\begin{abstract}
My mother asked me: 'You've been living in Berlin for 8 years. Will you apply for German citizenship?' For me, that was a strange question. I hadn't considered this possibility. I had no interest in exchanging my passport for a German one. I said 'No'. My mother was afraid that her son was no longer French [laughs]. [...] But I feel European. Through my passport I'm European and as such equal to German people in Germany.

French executive in Berlin
\end{abstract}

Living abroad or multilocally in two or more countries directly or indirectly raises the question of the social identification of migrants or translocal people. In migration theory, social self-identification is usually linked with the process and quality of

\footnotetext{
${ }^{1}$ This is the preprint version. The Copyright and final version "Mapping the social space of transnational migrants on the basis of their (supra)national belongings: the case of French citizens in Berlin" has been published on Taylor \& Francis Online and is available at: http://www.tandfonline.com/doi/full/10.1080/1070289X.2015.1008000.

${ }^{2}$ Researcher at the Institute for Sociology of the Basel University. c.duchene@unibas.ch

3 Associate Professor at the Department of Multimedia and Internet Careers (MMI) of University of Haute-Alsace. angeliki.monnier@uha.fr
} 
integration (Han 2010). While early integration models focused on the integration of migrants in the 'host' country, more recent models - which go beyond methodological nationalism - insist on transnational processes and the construction of a 'transnational social field' (Schiller, Basch, and Blanc-Szanton 1992), a 'transnational social space' ، (Pries 1998), or, more generally and more everyday life oriented, 'translocality' (Appadurai 1995). These changing models owe something to social developments. It is now sometimes technically easier to travel or communicate between certain geographically distant points - two European capitals, for instance (Ryan and Mulholland 2013) - than between places that are physically close to each other. It is also administratively easier to move and take up work within an integrating European space. We observe the 'archipelagization' (Viard 1994; Duchêne-Lacroix 2006; 2011) the social continuity of geographically separated frequented places - of households both nationally and transnationally. In this situation, transnationalism and local integration are not opposed processes (Erdal and Oeppen 2013). 'The multi-local life-world presents a wider, even more complex set of conditions that affect the construction, negotiation and reproduction of social identities' (Vertovec 2001). The question is not whether people live transnationally, but rather how and where are internationally multilocal people socially and locally integrated? What sorts of (supra/trans/bi/... national) identifications do they produce in this situation?

To answer these questions empirically, it's important to create a precise concept of identity and identify how it can affect the feeling of belongings. Roger Brubaker and Frederick Cooper (2000) question the relevance of identity as a category of analysis: according to these authors, the term, too ambiguous, too fluid, too overused, has lost its validity. In the same vein, Siniša Malešević $(2002,195)$ speaks of this concept as a 'normative straightjacket' and argues that its semantic ambiguity prevents it from being operationalized effectively in the social sciences. In response to these critiques of the concept of identity, Anthony Smith (2010, 18-20) acknowledges that identity is a polysemous concept but argues that that is also the case with other concepts used in the social sciences, such as class, state, ideology, etc., which are both categories of practice and categories of analysis. The difficulty of defining them does not, according to Smith, disqualify their heuristic relevance or legitimacy as objects of research. The working definition of identity adopted in this paper is that proposed by Alex Mucchielli, inspired by work in social psychology. Mucchielli $(2013,12)$ argues that identity is a set of meanings [...] attributed by social actors to a physical and subjective reality [...] regarding their experienced world, meanings constructed together with other agents'. In this vein, identity refers today to a sense of both the permanence of the self (the ipseity) and difference from others proposed by Paul Ricœur (1985) and the transaction with others (Ollivier 2007).

We therefore postulate a certain permanence in one's self-identification even if the multilocal context increases one's possibilities of identification, experiences and assignations. As Georg Simmel observed, 'The ego can become more clearly conscious of his unity the more he is confronted with the task of reconciling within himself a 
diversity of group interests' $(1999,417)$. We assume that the continuity of one's selfidentification is a product of the habitus. The symbolic construction of identity as a sense of belonging is based on a set of materiality and practices (social, discursive, etc.) (Koukoutsaki-Monnier 2013). In Pierre Bourdieu's sense, the latter constitute the habitus, the trends that people develop when they encounter and experience the material and symbolic structures which define their social and cultural practices (Bourdieu, 1980: 88). Materiality and the practices of collective life generate a body of knowledge and set of abstractions (codes, frames, prejudices, stereotypes, etc.) regarding one's own identity that are implicitly or explicitly consistent in transaction with others. We refer to these elements as representations, drawing on the Theory of Social Representations (Jodelet, 1989). Because of their normative power, representations act as interpretative frameworks (Goffman, 1991 [1974]) that nourish people's experiences of materialities and practices. Keeping this bidirectionality in mind is essential in order to understand the rigid - though not sealed - character of identity assignations. 'Habitus is constantly changing in response to new experiences [... but] never radically, because it operates from the premises established in a prior state' (Bourdieu 1997: 231).

As Bourdieu $(1997 ; 1972)$ has demonstrated, habitus differ according to the positions that individuals hold in various social fields. Consequently, the representations that social agents develop 'depend, in terms of content and symbolic force, on the position that those who produce them occupy; it is only through an analysis situs that these points of view can be reconstructed as such, i.e. as partial views taken from a point (situs) within the social space' $(1997,264)$. We can thus expect the feeling of belonging to be influenced by the interplay between the habitus, the different amounts of various capitals invested in specific (integration) fields, and the social composition of the multilocal living space. Conversely, a person - ego - can use his/her identity as a symbolic capital to cope with external conditions and constraints (Malewska-Peyre 2000). Through this framework, we can interpret multilocal life courses.

For instance, some working migrants invest all their time working in a host country not to acquire a social position 'here', but to send remittances 'there'. But they maintain too little contact with their social ties 'there', in the family field of the country of origin, and haven't invested the time to integrate socially or culturally 'here', in the host country (Sayad 1999). When they retire, they suffer from a twofold absence and the loss of identity. The migrant elite, because of its transnational activities, may also seem to be less locally integrated, but that's not necessarily true: it can be 'more cosmopolitan' than others while simultaneously displaying (multi)local integration and identification (Gustafson 2009), as is the case with the 'rooted cosmopolitans and transnational activists' of Sidney Tarrow (2008) and the small-scale import-exporters of Alain Tarrius (2000). Differences in integration and identification are observed both between and within national groups. The feelings of belonging differ for family members as they follow differing migration trajectories (Ley 2013). The identification differences between generations, and especially between first- and second-generation migrants, have been well established (e.g. Bolzman, Fibbi, and Vial 2003; Daha 2011; Jurt 2014; 
Sabatier 2008; Stroink and Lalonde 2009). What is less easy to find in the specialized literature is research that analyses the feelings of (supra/trans/bi/non-...) national belongings through the position of the ego in a 'social space' (Bourdieu 1979) within a national group. Social space is the result of the large interplay of different characteristics of people and their environment. We expected that within a national group of internationally multilocal people, the feeling of (supra/trans/bi/non-...) national belongings is linked especially with the level and quality of the ego's social, cultural and economic capital and the composition of the multilocal living space. To explore these relationships, we conducted empirical research.

After explaining the empirical method and describing the profile of the target population - French citizens in Berlin - the present article presents and discusses some results of the relationship between the variety of identity self-combining and the position of the ego in the social space (linked with his/her habitus and the amount and types of capital they possess).

\section{Empirical research on identity self-combining of French citizens in Berlin}

\section{The choice of French citizens in Berlin}

To explore the diversity of feelings of belonging within a national group of migrants and internationally multilocal people ${ }^{1}$, we searched for a national group of intraEuropean migrants (for the potential supranational European identification) with no particular collective stigma and no single social profile - such as 'guest workers' or expatriates from transnational firms. The diversity of the selected group was crucial in order to move beyond the idea that given categories naturally explain migrants' situations. Moreover, the population studied needed to be sufficiently large to make it possible to conduct a 'quantitative' survey. Last but not least, it was necessary for us to be able to establish a high degree of trust with this population. For these reasons, we chose French citizens living in Berlin. This investigation contributes also to the research on 'expatriates' who emigrate from one Western European country to another and do not belong exclusively to the labour migration of the 1950s and 1960s and their descendants.

Describing the profile of the French population in Berlin is challenging because of the dearth of administrative records in this regard, especially for a shifting migrant population (Below 1994; Duchêne-Lacroix 2007a). Berlin population records over 14 years reveal that this population is small (around 16,000 dual citizens in a total population of 3.4 million in 2008) but has risen steadily since the fall of the Berlin Wall (up from 5,500 civilians and around 2,500 military and allied personnel in 1987); young (average age 35); mixed (with almost equal representation of both sexes); and constantly renewed (with a high percentage staying for shorter periods: 50 per cent left after eight years applying the probability of emigration in 1990, and within four years applying the probability in 2000 and 2004). 
The former French military sector is no longer a structuring influence. The city-state now attracts French migrants for other reasons (business, education, visual and performing arts, diplomacy, etc.) and more than 10 per cent of these French citizens were born in Berlin. The shift in living places indicates this social shift: French citizens make up the largest group of foreigners in Prenzlauer Berg, a rapidly gentrifying district in the former East Berlin. This population includes a higher percentage of managers but also of clerical workers - than for the general population of France or Germany, but a smaller percentage than for other French populations outside France (DuchêneLacroix 2005). In contrast to the typical profile of expatriates, the French population in Berlin also includes a significant number of unemployed (who are not always proficient in German), retirees, and students. Lastly, there are manual workers, most of whom originally went to Berlin for military service and then stayed there.

According to our quantitative survey, on the whole the French population in Berlin has a high level of cultural capital: they have an excellent command of French and a good self-assessed command of German; at home, they speak French rather often but German more often; they have strongly internalized French culture; they have frequently completed several years of higher education (in the vast majority of cases in France); and they watch French television or listen to French radio rather often and watch German television or listen to German radio very often.

On average, the French population in Berlin maintains a rather active transcultural social network. Some 15 per cent are dual citizens (with 11 per cent holding French and German citizenships). The vast majority live in family households, with a majority married to German spouses; they have some to frequent social contact in Germany, mostly with Germans and less frequently with French people and third nationalities; and they maintain frequent contact with relatives in France and some contact with friends in France. Their social network rarely involves membership in associations: few belong to either German or French associations.

Lastly, most French citizens in Berlin feel well integrated in Germany and like their city of residence. Although a large majority feels close to German culture, they do not wish to acquire a second citizenship, and one-third plan to retire in France, one-quarter elsewhere in Europe, and only 16 per cent in Germany. At the time of the survey, however, the vast majority did not know whether they would settle permanently in Germany or not.

\section{What combination of identity categories?}

To tackle the difficulties to catch social self-identification the complexity of the identification possibilities has been reduced for the survey according to the content of the exploratory interviews. The interviewees used four main categories to self-identify with imagine communities: French/German/European/cosmopolitan. ${ }^{2}$ With the development of transnationalization, nation-states have not ceased to exist, to influence the course of everyday life, or to assign identities (Bommes 2003). In a transnational 
situation, cases of double national belonging based on identity documents are frequent. At the supranational level, aside from the oecumene, which would be associated with a 'Gaian' identity (Weichhart, Weiske, and Werlen 2006) or a cosmopolitan identity (Skey 2013), a European framework is now also discussed in major societal debates in Europe (Checkel and Katzenstein 2009; Kälble 1999; Kohli 2000). European identification can be a useful way of transcending national dichotomies or alternatives. It can be claimed alongside national identifications as their natural extension.

These four belonging labels was included in a question in the survey questionnaire: 'Do you feel...? French/German/European/cosmopolitan/something else (two empty fields). Up to two persons per household (always including a French citizen) filled out the questionnaire. The respondents could choose up to two identity categories and rank them. This question allowed multi-level combinations and hierarchies of identification categories: 'French', 'European', 'French-German', 'European and French', etc.). If a respondent answered with just one category, it was also an indicator of the negativity of the other proposed identity category: just German or just European also means, for instance, not French and not cosmopolitan. The sense of these categories of belonging, or labels, can also differ according to the position of ego: given or chosen, linked or exclusive (Duchesne 1997; Sencébé 2001).

\section{Which social space?}

The identity self-combining and ranking of French citizens in Berlin could be linked with their social position. To avoid an a priori 'groupism' (Brubaker 2006) of the selected population we constructed the social space empirically through the associations between the answers to the questionnaire that are also associated with specific selfcombinations of belonging categories. The respondents (first and second person of household) were interrogated about a large variety of topics: their origins, their mobility practices, the composition of their household, their activities, their language level and practices, the spatial distribution of their social networks and how integrated they were in them, their civic participation, their consumption of information, their opinion about their integration, and their living places. We situated these topics in the 'country of origin' and the 'country of destination' to build an overview of the multilocal attachments of the ego. ${ }^{3}$ It should be noted that the individuals and their identity choices, and even the particularities of the social space, are not considered to be static but dynamic and slightly different in different local fields.

\section{Empirical material}

A mixed method research was conducted between 2000 and 2004. A postal survey was sent to 3,000 households of which at least one member was a French citizen, and almost 1,000 questionnaires were returned. In addition, we conducted 50 semi-structured interviews with respondents to the questionnaire on the same topics as in the survey, studied extracts from 14 years of population registers, and carried out participant 
observation. For this article, following the method of Philippe Cibois (2007), from the survey we selected the variables associated with the belonging question as the 'interest variable'. Some variables were not associated with this interest variable (change in household income, relocation, membership in an association (either French or German), or French region of origin). Then we calculated a multiple correspondence analysis (hereafter 'MCA') with all the variables associated with this interest variable.

\section{General description of the MCA}

The choice of identity combinations, their diversity and the relationship between them can be interpreted through their position in the produced social space - that is, through the distance and proximity of these combinations with other combinations and with the modalities of other variables (figure 1). We interpreted and named the first two axes through the scatter of the modalities. The axis 'German versus French area' distinguishes between people anchored in the French culture area with little participation in the German area and people integrated into German society or culture with little participation in French society or culture. The vertical axis, 'Intensity of integration and level of capitals', describes the intensity of the integration in the French and German spheres or outside those frameworks and the level of various capitals the ego possesses. This distinction between the degree of integration and the place of integration already produces an interesting result: some respondents are more or less integrated in one or both countries, and the degree of integration is linked with certain identity combinations. Furthermore, the 'Intensity of integration and level of capitals' axis separates the combinations with a European identity from the other combinations. The European category is more present in the identification of those who have a higher degree of integration and are endowed with more of the various types of capital. French citizens in Berlin more frequently chose the 'European' category in their identity combinations than does the general population of any EU country surveyed for the Euro-barometer (Duchêne-Lacroix 2007a; Duchêne-Lacroix 2007b). It is possible that those French citizens in Berlin with very low integration in the French culture area are under-represented in the survey for the simple reason that they may have been unlikely to answer the questionnaire.

\section{'Franco-German' and 'French then European' opposed in the 'German versus French areas' axis}

The 'Franco-German' and 'French then European'4 modalities are on the same line on the 'intensity of capitals' axis, and opposed on the 'German versus French area' axis and contribute to it. The 'Franco-German' combination (11 per cent of respondents) attracts the modalities of good integration in Germany and less good integration in France. The 'Franco-German' identity does not hold a central position in the diagram, halfway between the French area and the German area. In fact, there is an identity asymmetry because the study concerns French people in Berlin, i.e. although these 
individuals are more integrated in the German area than in the French area, their French citizenship still influences their self-definition. Inversely, although the respondents live in Germany, the German identification is a minor category in the chosen combinations (14 per cent) and is almost always combined with the French one. Most frequently 'Franco-German' respondents want to retire in Germany, have no intention to settle in France, have little contact with friends in France, socialize almost exclusively with Germans, have a secondary-education level (neither less nor more), have French and German citizenships, arrived or were born in Germany between 1951 and 1970, subscribe to a German magazine (and not to a French one), live with a person who also feels close to Germany, and are clerical workers or self-employed.

\section{FIGURE 1 HERE}

On the 'French' side of the 'German versus French areas' axis, the 'French then European' identity combination is closer to the centre than any other combination. One reason for this is that 'French then European' is the most frequently chosen combination, which draws it towards the centre more than the other combinations. The 'French' belonging attracts the inverse modalities to those that characterize the typical profiles of 'Franco-German' respondents: they were educated in France and not in Germany; they subscribe to a French magazine and not to a German one; they want to retire in France and not in Germany; they foresee a return to France within the next five years, especially because they consider France to be home and have a good quality of life; they have some or frequent contact with France (some of them have their main residence in France); and they moved to Berlin (and Germany) more recently than other respondents. Other integration aspects are less extreme (intermediate to good command of German, feeling somewhat close to Germany, difficulties in making friends in Germany).

\section{'European then French' versus 'French'/'Franco-cosmopolitan' on the 'intensity of integration and level of capitals' axis}

The 'European then French' respondents are relatively more integrated and endowed with more capitals on the 'intensity of integration' axis and in a medium position on the 'French versus German areas' axis. Relative to the other groups, more people who chose this combination are executives; have a postgraduate education; have Internet access; subscribe to both French and German magazines; have a bank account in France; and have a home in France, either rented out or as a second home. They, like their spouses, feel socially and culturally closer to German society than do 'French then European' or 'French' respondents. Relative to the other groups, they vote more frequently in EU elections and more in France, and they more frequently intend to retire outside Europe or somewhere in Europe but not necessarily in France or Germany. A larger proportion than in other groups has spent three to five years in a third country, 
while fewer of them have never lived or have lived for more than five years in a third country. People who have a majority of the modalities close to the 'European then French' identification are better off economically and possess more social, cognitive, and cultural resources and skills.

But it's not just a question of capacity, but also of practices, norms, and the influence of social circles. Herman, an academic, said: 'Many of my French friends tell me I've become Germanized. [...] Some think I'm avoiding my responsibilities by not working full-time in a French university'. His identity definition is ambivalent. He defines himself first as 'Someone who is neither French nor German. [...] Foreign countries are other countries with which I have no familiarity. [...] I've had 17 years of working and family life in Germany'. But later:

Oh, I'm French [...] for the reasons I mentioned earlier. I was socialized in France [...]. I'm a product of the French higher-education system. [...] Everything about me shows it. I'm more than that but I am that. [...] I've never considered applying for another passport; I don't even know if I'm eligible. But here I am a German professor. I'm a German professor institutionally and in the way I teach and participate in committees. I function like a German and I'm thought of as an insider.

Herman's cultural belonging is ambivalent, reinforced by his multilocal practices for occupational and family reasons, his successive socialization experiences, and the judgements of his interlocutors in France and Germany. In addition he feels European as a result of citizenship and where he lives and as a way of combining his two cultural influences and competencies. Here the choice to self-define as 'European then French' is a way of transcending the national framework, which is too narrow, without erasing his origins, which can be a resource. This positioning is often found in two other cases of identity belonging: 'European/cosmopolitan' and 'European'.

The 'French' singleton and the 'Franco-cosmopolitan' combination, close to each other, are opposed to the 'Franco-German' combination on the 'French versus German areas' axis, and opposed in particular to the 'European and French' combination on the vertical 'intensity of integration/level of capitals' axis. Around the exclusively 'French' belonging (around 13 per cent of the respondents), the modalities indicate a lack of capitals and little integration into either German and French society: a low to medium level of German; few contacts with people in Germany; many problems with neighbours; many difficulties making friends; low identification with German society for both the first and the second person in the household; no participation in EU elections; and a higher rate of unemployment. A return to France is considered for family reasons (e.g. the spouse's occupation). More respondents of both groups have never lived for more than five years in a foreign country.

How can the association between feeling exclusively French and low integration be interpreted? First, the choice of a single category is telling. In the questionnaire, respondents could choose up to two identity belongings, including an open choice. Choosing only one identity therefore intensifies it and places it in stronger opposition to the other categories (German, European, cosmopolitan, other, or nothing). More than 60 per cent of the respondents chose two categories. Secondly, this strong choice is made 
by French citizens who live outside France. Although these people live in an 'otherness' situation in which the dominant nationality and culture is German, they make no place for hybridity. The case of Stephanik suggests an interpretation of this identity choice.

Stephanik proudly recounted that he came to Berlin for military service as a volunteer to monitor the Wall. He describes himself as French, 'French as a second nationality too'. He would never apply for German citizenship because he considers it an insult. French citizenship is his most precious asset, and he describes it in naturalistic terms. He is French just as he is a man, white, etc., although he says he does not feel at all superior to other nationalities or 'races'. He comes from a modest social background. He has no qualifications except a truck driver's licence, which he earned in the army. His situation is difficult, but he says proudly: 'Do you know how many times I've been unemployed? Never!' Throughout the interview, he frequently oscillated between the need to show that he is coping on his own and the desire for more solidarity between French migrants, because he believes nationality should override other divisions and create a natural fraternity, like a big family. Compared to Turks in Berlin, one of Berlin's largest ethnic minorities, he believes that the French 'community' is socially divided and lacking in solidarity.

We received a piece of paper saying the chairman of the French association in Berlin is Mr So and So, the boss of such and such, Lafayette or something, some guy with a tie, you know what I mean? [...] Do you think he’s going to understand us? [...] Why don't they put a working-class man [...] who understands the problems we have? Because there are loads of French people here who have problems.

Stephanik's national identity is, first, a natural or given characteristic that can't be exchanged or combined. Second, it represents his paradigm of social and political organisation. French leaders have to resolve the problems of all French communities throughout the world. Third, it is the only positive symbolic resource he can use to cope with problems in society. In Stephanik's view, the ties of nationality transcend all other social belongings. This national identification is thus somewhat similar to the model of French citizenship by heritage proposed by Sophie Duchesne (1997).

The 'French' identity as the only symbolic capital and resource for French citizens with low integration and limited capitals to cope with problems abroad - this analysis is too simple. Other French citizens who also have a relatively low level of integration and capital chose another self-identification: 'French/cosmopolitan' (about 8 per cent of respondents). Considering the interpretation of the exclusive 'French' identification in the case of Stephanik, it is hard to understand the meaning of a combination that contains the 'cosmopolitan' category chosen by people with low levels of integration. A cosmopolite is someone with international experience who is at home everywhere (Skey 2013). He has cultural and linguistic resources, strong interpersonal skills, and 
connections. One of our interview subjects gives us insight into this apparently strange association. Evelyna is a white French artist in Berlin who claims to have been a victim of xenophobia who did not receive aid from local authorities. Her humanist ideal is to be accepted as a full member of her society of residence, to transcend national cultural differences, and to be accepted and even recognised for the identity that she wants to show, i.e. an artist. She feels that people constantly assign a foreign identity to her. She uses this assignation as evidence that people put up barriers against her. She does, however, describe her French identity as an occasional advantage in her occupation or everyday life. It is not possible to determine whether her decision to become an artist was influenced by a particular psychological background or whether the difficulties she has had in establishing herself as an artist without connections or a high language level have influenced her psychological and social path. Her decision to come to Berlin was connected to a need to leave France, which she felt was imposing another social barrier (moreover, she wants to retire outside France), even though she chose the French identity category as evidence of her cultural capacities. Lastly, if we turn the interpretation around, the 'cosmopolitan' category could be a positive expression of a lack of social anchoring, while French citizenship could be a positive default foreign identity, i.e. French/cosmopolitan is the reverse of 'from nowhere and elsewhere'.

A third group of belonging, the 'other' identity, groups all the identifications that were too small to constitute a group on the MCA map. At least half of the cases in the 'other' category contain a German identity category, which is why it is situated on the German part of the 'French versus German areas' axis. Around the 'other' identity converge low integration indicators and in particular low French integration indicators: these individuals speak fewer languages at home, do not subscribe to French or German magazines; possess less than a medium level of French; have only German friends; have little or no contact with friends in France; do not have Internet access; and do not have a bank account in France. Respondents with this identity are more frequently retired, came to Berlin for military service before 1950, and intend or continue to spend their retirement in Germany. According to an employee at the French Embassy, people with French citizenship who have difficulty speaking French are not rare; they tend to be old migrants or young Franco-Germans. Beyond the question of the low-integration position, we propose two scenarios in which respondents who have French citizenship identify themselves as partly or exclusively German but not French: on the one hand, migrants or their descendants who have cut off or don't maintain ties with France and have contacts in Germany; on the other hand, German women who automatically acquired their husband's French citizenship upon marriage (possible before 1974), but who never assimilated a French identity either emotionally or civically. 


\section{Between 'Franco-German' and 'European then French': the 'European' and}

\section{'European/cosmopolitan' identifications}

The 'European/cosmopolitan' (8 per cent) and 'European' (11 per cent) modalities are located between the 'Franco-German' and 'European then French' modalities, i.e. between categories that represent a high degree of integration in Germany and categories that represent a high degree of integration in France and Germany simultaneously. Approximately 23 per cent of respondents declared a belonging combination or a simple 'European' belonging, with no attachment to any national category. In both cases, and in the 'European then French' case, the 'European' category may have been chosen to create some room in the identity assignation and transcend the national framework.

The exclusively European identity is very close to the Franco-German axis and rather close to the Franco-German identity zone, which might seem surprising. We might have expected the European singleton identity to be close to the 'European then French' zone with integration indicators in at least two areas, French and German. A European identity offers an escape route from French/German (failed) assignations. Marco's situation sheds light on this positioning. He's a student born in Germany with French and German parents and describes himself as European. 'I spend holidays in France. [...] When I'm on holiday in France and talk to people, I sense when they think I'm German, and it pisses me off. [...] But after I come back from France when I speak German, I have trouble stringing a sentence together. It's like I'm disabled'. The combination of difficulty with language and cultural competencies (knowing the cultural references of one's peers, music, TV series, etc.) and difficulties with an assigned (failed) identity can encourage the choice of a synthetic identity, which makes it possible to avoid judgements that disqualify one or both sides of a Franco-German identity in other people's eyes. A European identity is the solution.

Another case of a non-national belonging combination is a heuristic test for our integration concept between France and Germany. Gina describes herself as a Parisian and cosmopolitan. She is married to a German senior executive of a multinational company. We met her for the first time at a concert by the Berlin Philharmonic accompanied by two ambassadors and senior executives. She recounts selected aspects of her life that emphasize her elite internationality and distance her from common identity standards, national institutions (such as the French community in Berlin with the embassy at its centre, with which she associated us during the interview), and nonstatus-enhancing places. For example, she claims she would never have followed her husband if he had stayed in his provincial German hometown and emphasizes her experience of living in Tokyo and the art exhibitions she organizes in major world cities. She sees herself as belonging to an elite without national borders but with 'archipelagized' geographical borders (Paris, Tokyo, Berlin-Grünewald but not a provincial city or East Berlin; socializing with foreign ambassadors' wives in Berlin but not with the French community in Berlin). Although she registered with the French 
Embassy, she did so for practical reasons - in case she loses or needs to renew identity documents, such as her passport, which is 'useful for travelling'. Gina is globally integrated into German and French society, but not into local 'plebeian' German and French communities.

\section{Conclusion}

Through this exploratory analysis, we wanted to discover, first, the diversity of (supra/trans/bi... national) belongings within a foreign population that shares the same nationality (French) and the same region of residence (Berlin); second, the relationship between these belongings and the social space of this population; and third, the meaning of the belongings both as combinations and as elements of a combination for this population.

It is not easy to empirically investigate the question of identity in a transnational social space, and it does not appear to have been done before. In our empirical study of French citizens in Berlin, we have conducted an exploratory multiple correspondence analysis using the interest variable method 'belonging' on the 'quantitative' dataset and an analysis of some of the interviews. We found that, of the 25 belonging combinations possible from the ability to choose up to two of six categories - French, German, European, cosmopolitan, other (which respondents were required to specify), and nothing - seven combinations account for 92 per cent of the responses. These belongings are more or less distant from each other in the social space. The choice of the belongings is influenced by the respondents' amount of social, cultural, and economic capital (with indicators like educational level or professional status, location, and intensity of contacts) and the intensity and the types of integration within the French and German areas that structure the social space. The two main axes differentiate the intensity of integration/level of capitals from the French and German areas of integration/capitals. That is, for this population simultaneous or asymmetrical high/low integration in two areas is not just a possibility, but a fact.

The belonging combinations are socially situated. To sum up briefly, more people whose identification is either 'French' or 'French/cosmopolitan' have a very low degree of integration into the German culture area and a low degree of integration into the French culture area compared to the other respondents. More 'European' and 'European then French' profiles are associated with high integration indicators in both the French and German areas than other groups. More 'Franco-Germans' and 'Europeans' are well integrated in the German culture area and less well integrated in the French area than other respondents; conversely, those who say they are 'French then European' more frequently show a medium degree of integration in the German culture area and greater integration in the French culture area.

The ranking of the identity categories in the declared belonging combinations is important: there is a considerable difference in integration between respondents who feel 'French then European' and those who feel 'European then French', with the latter 
group tending to have higher socio-occupational and education levels and to feel closer to Germany than the former group (e.g. Hermann's case in this article). For French citizens in Berlin with a low level of integration and little by way of various types of capital, the French identity can represent a natural part of their being, without adjuncts or alternatives, as a heritage (Duchesne 1997) and not a choice, sometimes as a symbolic capital. Indeed, some French citizens use the European identity alone to avoid the difficulties of having two nationalities and national assignations in everyday life. This exclusively European identity is here an alternative to Franco-German belonging with a very similar integration profile. Others chose no national identity as a way of distancing themselves from insufficiently valuable identities and from members of the 'French community in Berlin' who endorse a national assignation and supposedly live in a local national community. Gina described herself as being without barriers, as a Parisian and cosmopolitan, since Paris is a global metropolis, which she connects with other hubs in an international archipelago.

Figure 1. Social space of the French inhabitants of Berlin on the basis of their (supra)national belongings. Source: pathway survey. Copyright: Cédric Duchêne-Lacroix.

Beyond the question of the value of identity categories, several meanings for the same identity category appear, depending on respondents' profiles. That is, a single identity category, such as 'cosmopolitan', 'European', or 'French', can't on its own predict a position in the social space, but the ways in which these categories are combined (including the decision to choose only one) can. National identity can be reified and exclusive (stronger identity) or contingent (weaker identity). 'Cosmopolitan' - like 'French' - can represent a way of putting a positive spin on a low level of local integration, but without the cultural or social capital that is expected with this identity category. Conversely the 'cosmopolitan' category is also used to distinguish those who chose it from the locally or nationally integrated community as belonging to a transnational network of top leaders and frequent international travellers. Tarrow analysed a third position: 'rooted cosmopolitans' (Tarrow 2008). A ‘European’ identity can offer a way out of the assigned Franco-German alternative, which is often challenged by each national society. But for others, it is also a logical sub-identity of the national one: I'm French, but I'm also European.

As we know regarding national identity (Koukoutsaki-Monnier 2013), (supra/trans/bi/mono... national) belongings are non-essentialist products of the interplay of different factors. The proposed identity categories reproduce labels commonly used in everyday life and cited in exploratory interviews, but the respondents had the choice to combine categories. This article has analysed the ideal-typical proximities between belongings, levels of integration, and the amount of different types of capital possessed, with a focus on two national living contexts, and it has proposed empirical patterns to understand the embedding of the belonging self-combinations. The result is a series of social photographs 'as partial views taken from [different] point[s] (situs) within the social space' (Bourdieu 1997, 264) and at a specific moment for the 
persons and the society. As habitus, identity belonging is not 'destiny'. Some respondents described parallel changes over the course of their lives in their sense of belonging and in their social circles or in societal events - but also in the accumulation of experiences and dispositions (Duchêne-Lacroix 2007a). Some identity potentialities are activated or inhibited, improved or diminished within certain conditions. However, some configurations could present a greater stability. Some relatively fine differences, such as whether one chooses to self-identify as European or not, seem to be more profound indicators of the social groups to which one belongs. This particular distinction - 'European' or not - seems to be incorporated into the habitus of many inhabitants in Europe as an indicator of a social identity (Duchêne-Lacroix 2007a). The habitus configuration could play a role: Stephanik, one of our interviewees, thought of his French identity in exclusive, quasi-essentialist terms. His national identification is stable. In contrast, Hermann's self-identity definition appears to be more unstable, more open, and also more reflexive. He has more cultural capital, but also a more contradictory Bourdieu's dispositions.

This window into the ways in which individuals self-identify offers an example for further, deeper analyses of the configuration of social identity beyond methodological nationalism while retaining the identity categories that people use in their daily lives to identify themselves and others. This exploratory analysis has to be confirmed and extended in many directions, through the investigation of other national groups in other places.

\section{Endnotes}

${ }^{1}$ With regard to other research topics: What is a national "presence"? How people cope with social identities, cope with absence in transnational situation and construct own territoriality?

${ }^{2}$ Local, regional or religion (for instance Muslim) identities were much less frequent but interesting qualitatively. Biographical and occupational identities were normalized in the questionnaire.

${ }^{3}$ This approach is comparable to that of the research team of Godfried Engbersen regarding migrants from Central and Eastern Europe in the Netherlands (Engbersen et al. 2013)

${ }^{4}$ Statistically, the profile of those who chose the categories - "French" and "European"

- is different of the profile of those who chose "European then French". Both groups were big enough to constitute separated them.

\section{References}

Appadurai, Arjun. 1995. "The Production of Locality." In Counterworks: Managing the Diversity of Knowledge, edited by Richard Fardon, 204-25. London: Routledge.

Below, Sigrun. 1994. "Qualität der Einwohnermelderegister und ihre statistische Nutzung - eine Literaturstudie.” Statistischer Monatsschrift des Berliner statistischen Landesamtes 6. 
Bolzman, Claudio, Rosita Fibbi, and Marie Vial. 2003. Secondos - Secondas: Le processus d'intégration des jeunes adultes issus de la migration espagnole et italienne en Suisse. Editions Seismo.

Bommes, Michael. 2003. "Migration in der modernen Gesellschaft.” Geographische Revue 5 (2): 41-58.

Bourdieu, Pierre. 1972. Esquisse d'une théorie de la pratique: précédé de Trois études d'ethnologie kabyle. Seuil.

— 1979. La distinction. Paris: Éditions de Minuit. 1997. Méditations pascaliennes. Édition : édition revue et corrigée. Paris: Seuil.

Brubaker, Rogers. 2006. Ethnicity without Groups. Édition: New Ed. Cambridge, Mass.: Harvard University Press.

Brubaker, Rogers, and Frederick Cooper. 2000. "Beyond identity”. Theory and Society 29 (1): $1-47$.

Checkel, Jeffrey T., and Peter J. Katzenstein. 2009. European Identity. Cambridge University Press.

Cibois, Philippe. 2007. Les méthodes d'analyse d'enquêtes. Paris: Presses Universitaires de France - PUF.

Daha, Maryam. 2011. "Contextual Factors Contributing to Ethnic Identity Development of Second-Generation Iranian American Adolescents.” Journal of Adolescent Research 26 (5): 543-69.

Duchêne-Lacroix, Cédric. 2005. "Les Français établis hors de France. Une population méconnue et en transformation." In La population de la France: évolutions démographiques depuis 1946, Volume 2, edited by Christophe Bergouignan, Chantal Blayo, Alain Parant, Jean-Paul Sardon, and Michèle Tribalat, Conférence Universitaire de Démographie et d'Étude des Populations, 2:847-58. Paris: INED.

2006. "Von französischen zu plurikulturellen Archipelen: Lebensformen von Franzosen in Berlin.” In Transnationale Karrieren: Biografien, Lebensführung und Mobilität, edited by Florian Kreutzer and Silke Roth, 240-58. Wiesbaden: VS Verlag für Sozialwissenschaften.

2007a. Archipels transnationaux et agencements identitaires: Présences françaises à Berlin/Transnationale Archipele und Identitätszusammenstellung - Französische Präsenzen in Berlin. 2 vols. Lille: ANRT.

. 2007b. "La place de l'Europe dans l'identité socioterritoriale des Français de Berlin.” Revue des Sciences Sociales, no. 37: 68-77.

. 2011. "Archipel." In Praxen der Unrast: Von der Reiselust zur modernen Mobilität, edited by Jens Badura, Cédric Duchêne-Lacroix, and Félix Heidenreich, 135-46. Berlin-Münster-Wien-Zürich-London: Lit-Verlag.

Duchesne, Sophie. 1997. Citoyenneté à la française. Paris: Presses de Sciences Po.

Engbersen, Godfried, Arjen Leerkes, Izabela Grabowska-Lusinska, Erik Snel, and Jack Burgers. 2013. "On the Differential Attachments of Migrants from Central and Eastern Europe: A Typology of Labour Migration.” Journal of Ethnic and Migration Studies 39 (6): 959-81.

Erdal, Marta Bivand, and Ceri Oeppen. 2013. “Migrant Balancing Acts: Understanding the Interactions Between Integration and Transnationalism.” Journal of Ethnic and Migration Studies 39 (6): 867-84.

Gustafson, Per. 2009. “More Cosmopolitan, No Less Local.” European Societies 11 (1): 25-47.

Han, Petrus. 2010. Soziologie der Migration: Erklärungsmodelle, Fakten, Politische Konsequenzen, Perspektiven. Auflage: 3., überarb. Aufl. Stuttgart: UTB, Stuttgart.

Jurt, Joseph. 2014. "Secondos/Secondas. La situation de la deuxième génération d’immigrés en Suisse et leur littérature.” In Migration et identité, edited by Thomas Klinkert, 31-46. Freiburg: Rombach Verlag.

Kälble, Hartmut. 1999. “Europäische und nationale Identität seit dem zweiten Weltkrieg.” In Demokratie in Deutschland: Chancen und Gefährdungen im 19. und 20. Jahrhundert. historische Essays, edited by Wolther von Kieseritzky and Klaus-Peter Sick, 395-419. München: Beck. 
Kohli, Martin. 2000. “The Battlegrounds of European Identity.” European Societies 2 (June): 113-37.

Koukoutsaki-Monnier, Angeliki. 2013. "Pour une approche pluridimensionnelle de l'identité nationale.” Revue ¿Interrogations? 16 (Identité fictive et fictionnalisation de l'identité (II)): online.

Ley, David. 2013. "Does Transnationalism Trump Immigrant Integration? Evidence from Canada. Links with East Asia.” Journal of Ethnic and Migration Studies 39 (6): 92138.

Malešević. 2002. "Identity: Conceptual, Operational and Historical Critique." In Making Sense of Collectivity: Ethnicity, Nationalism and Globalisation, edited by Siniša Malešević and Mark Haugaard, 195-217. London: Pluto Press.

Malewska-Peyre, Hanna. 2000. "L’identité Comme Stratégie.” In Pluralité Des Cultures et Dynamiques Identitaires: Hommage À Carmel Camilleri, edited by Carmel Camilleri, Jacqueline Costa-Lascoux, Marie-Antoinette Hily, and Geneviève Vermès. Editions L'Harmattan.

Mucchielli, Alex. 2013. L'identité. Presses Universitaires de France - PUF.

Ollivier, Bruno. 2007. Identité et identification: sens, mots et techniques. Hermès science publications.

Pries, Ludger. 1998. “Transnationale Soziale Räume.” In Perspektiven Der Weltgesellschaft, edited by Ulrich Beck, 55-86. Frankfurt a. M.

Ricœur, Paul. 1985. Temps et récit: Le temps raconté. Paris: Seuil.

Ryan, Louise, and Jon Mulholland. 2013. "Trading Places: French Highly Skilled Migrants Negotiating Mobility and Emplacement In London.” Journal of Ethnic and Migration Studies 0 (0): 1-17.

Sabatier, Colette. 2008. "Ethnic and National Identity among Second-Generation Immigrant Adolescents in France: The Role of Social Context and Family." Journal of Adolescence, Adolescent Self and Identity Development in Context, 31 (2): 185-205.

Sayad, Abdelmalek. 1999. La Double Absence. Des illusions de l'émigré aux souffrances de l'immigré. Liber. Paris: Seuil.

Schiller, Nina Glick, Linda Basch, and Cristina Blanc-Szanton. 1992. "Transnationalism: A New Analytic Framework for Understanding Migration.” Annals of the New York Academy of Sciences 645 (1): 1-24.

Sencébé, Yannick. 2001. "Les lieux et les temps de l'appartenance sociale. Mobilité et territoire: une analyse sociologique du Diois. Rural community of the Diois area of France”. Lyon: Université Lumière, Lyon II.

Simmel, Georg. 1999. Sociologies: Etudes sur les formes de la socialisation. Translated by Lilyane Deroche-Gurcel. Paris: Presses Universitaires de France - PUF.

Skey, Michael. 2013. "What Does It Mean to Be Cosmopolitan? An Examination of the Varying Meaningfulness and Commensurability of Everyday ‘cosmopolitan' Practices.” Identities 20 (3): 235-52.

Smith, Anthony D. 2010. Nationalism. Polity.

Stroink, Mirella L., and Richard N. Lalonde. 2009. "Bicultural Identity Conflict in SecondGeneration Asian Canadians.” The Journal of Social Psychology 149 (1): 44-65.

Tarrius, Alain. 2000. Les Nouveaux Cosmopolitismes: Mobilités, Identités, Territoires. Aube.

Tarrow, Sydney. 2007. "Cosmopolites Enracinés et Militants Transnationaux”, Lien social et politiques 58: 87-102.

Vertovec, Steven. 2001. "Transnationalism and Identity.” Journal of Ethnic and Migration Studies 27 (4): 573-82.

Viard, Jean. 1994. La Société d'archipel ou Les Territoires du village global. La Tourd'Aigues: L'Aube.

Weichhart, Peter, Christine Weiske, and Benno Werlen. 2006. Place Identity and Images: Das Beispiel Eisenhüttenstadt: Mit Beiträgen von Gerhard Ainz Und Christoph Sulzer Sowie Marco Mehlin. 1st ed. Vol. 9. Abhandlungen Zur Geographie Und Regionalforschung. Wien: Universität Wien Institut für Geographie und Regionalforschung. 